\title{
TOXICOCHEMICAL ANALYSIS OF ARSENIC IN BROILER CHICKEN; IMPLICATIONS FOR HUMAN RISK ASSESSMENT
}

\author{
J.G.P.S Ubesena, B.A Perera ${ }^{*}$ and S.P Deraniyagala \\ Department of Chemistry, University of Sri Jayewardenepura, Sri Lanka \\ E-mail-basirip@yahoo.com*, Tel-++ 9477397 0350,Fax- ++ 94112802914
}

\begin{abstract}
Among the general public, the word "arsenic" has become almost synonymous with the word"poison" because of its toxic nature to humans. Although there has been considerable concern about the adverse effect of arsenic present in drinking water, the risks of arsenic in food have received less attention. The main purpose of this study was to estimate the total arsenic concentration in different tissues (breast, liver and heart) of broiler chicken in different brands available in the Sri Lankan market. Graphite furnace atomic absorption spectrometry (GF-AAS) was used subsequent to dry ash preparation with the presence of $\mathrm{Mg}\left(\mathrm{NO}_{3}\right)_{2}$ as the ashing aid. The accuracy of the technique was evaluated by using spiked chicken breast sample; the percentage recovery of total As was observed as $105.7 \%$. The concentrations of total arsenic in different brands of broiler chicken were found in the ranges of $0.65-0.85,0.42-0.52$ and not detectable- $0.08 \mu \mathrm{g} \mathrm{g}^{-1}$ on wet basis with respect to the brands "A", "B" and "C". Some of the tested breast tissue samples violated the tolerance limit $\left(0.5 \mu \mathrm{g} \mathrm{g}^{-1}\right)$ for total residue of arsenic in chicken meat set by the US-FDA. These values are also higher than the values observed in a market study in the United States, during 1991-1996 and lower than the arsenic values reported in Pakistan in 2007. The variation of mean total arsenic concentrations in breasts, liver and heart tissues within the brand "C", was observed as $0.04,0.33$ and $0.30 \mu \mathrm{g} \mathrm{g}^{-1}$ on wet basis. These observations conclude that liver and heart tissues contain relatively higher amounts of total arsenic than breast tissues.
\end{abstract}

Another purpose of this study was to estimate total and inorganic arsenic ingested by humans through chicken consumption and thereby make implications for human risk assessment. Taking into account observed total arsenic concentrations of breast muscle tissues in this study and $65 \%$ from the total as inorganic arsenic, the inorganic and total arsenic ingested by eating chicken was calculated. Considering average levels of chicken consumption as $60 \mathrm{~g} /$ person/day, people may ingest as much as 44.90, 28.29 and $2.10 \mu \mathrm{g}$ of total arsenic/day, which is equivalent to $29.19,18.39$ and $1.37 \mu \mathrm{g}$ inorganic arsenic/day from brands " $\mathrm{A}$ ", "B" and "C", respectively. For a person weighing $60 \mathrm{~kg}$, the inorganic arsenic intake would be $0.49,0.31$, and $0.02 \mu \mathrm{g} / \mathrm{kg} / \mathrm{day}$ and contributes $23.77,14.60$ and 1.09 percentages by chicken alone out of the FAO/WHO tolerable daily intake which is $2.1 \mu \mathrm{g} / \mathrm{kg} /$ day received from all dietary sources. Moreover, arsenic was tested among the cooked chicken breasts which were subjected to different cooking recipes and it was found that the cooked chicken breast tissues had total arsenic closer to $1 \mu \mathrm{g} \mathrm{g}^{-}$ 1; none of them were below the maximum permissible level. These studies suggest that the cooking methods do not have any impact on removing arsenic.

Keywords: arsenic, chicken, drug residue, GF-AAS, risk assessment

\section{INTRODUCTION}

Arsenic is a heavy metal that is found in inorganic and organic forms in water, food, soil, dust, wood, and other materials. Inorganic forms of arsenic have been classified as human carcinogens and are

Proceedings of the 15 $5^{\text {th }}$ International Forestry and Environment Symposium, 26-27 November 2010.

Published by Department of Forestry and Environmental Science, University of Sri Jayewardenepura, Sri Lanka. 
more toxic than organic forms, but variation in toxicity among inorganic and organic forms is considerable. Chronic arsenic exposure in the range of $0.01-0.04 \mathrm{mg} / \mathrm{kg} /$ day has been associated with skin cancer in Taiwan (Hsueh et al., 1995); respiratory cancers in Montana (Lubin et al,. 2000); bladder cancer in Finland (Kurttio et al., 1999); increased mortality from hypertensive heart disease, nephritis and nephrosis, and prostate cancer in Utah (Lewis et al., 1999); increased incidence of lung cancer, bladder cancer, and all cancers in Taiwan (Chiou et al., 1995); late fetal mortality, neonatal mortality, and postnatal mortality in Chile (Hopenhayn-Rich et al., 2000); and cytogenetic damage in Mexico (Gonsebatt et al., 1997). The general population is exposed to arsenic through drinking water, dust, fumes, and dietary sources, with the highest concentrations of arsenic reported in seafood, rice, mushrooms, and poultry (Tao and Bolger 1999).

Arsenic has been found in all foodstuffs. The total arsenic concentrations in foodstuffs from various countries vary widely depending on the food type, growing conditions, and processing technologies (Szkoda et al., 2006). Researchers from the National Institutes of Health and the USDA's Food Safety Inspection Service recently reported alarmingly high levels of arsenic contamination in the flesh of broiler chickens (Lasky et al., 2004). The commercial feeds of broiler chicken contain mixtures of plant-based products, as well as other ingredients ranging from rendered animals to animal waste, antibiotics and organoarsenicals (Wershaw et al., 1999; Jackson and Miller, 2000). Roxarsone (4hydroxy-3-nitrophenyl arsonic acid) is the most frequently used additive among a group of organic arsenic compounds added to feed of broiler chickens and it is administered to feeds at concentrations ranging from $22.7 \mathrm{~g} /$ ton to $45.4 \mathrm{~g} /$ ton to control coccidial intestinal parasites(Chapman \& Johnson, 2002). Roxarsone contains organic arsenic in the +5 oxidation state.

We quantified the concentrations of total arsenic in broiler chicken using three different top brands available in Sri Lankan market and also this is the first report of arsenic concentrations in national samples of poultry in Sri Lanka. This may be useful in risk assessments of arsenic exposure and its consequences. We also estimated the dose of inorganic and total arsenic delivered with varying levels of chicken consumption, and the risk for high levels of arsenic exposure through chicken consumption alone.

\section{EXPERIMENTAL}

\subsection{SAMPLE COLLECTION}

Healthy mature broiler chickens, whose weight and age ranged 1200-2000 g and 6-8 week, respectively, were purchased from the markets of Colombo (Sri Lanka) in 2009-2010. Each collected chicken was purchased differently in muscles type (breast, liver and heart). Then each of the muscle tissues were washed separately with deionized water and dried by using filter papers to remove additional water. The dried samples were stored in a refrigerator at $-4{ }^{0} \mathrm{C}$ until analysis.

\subsection{REAGENTS}

High purity deionized water (produced in lab using a Bhanu aqua DM 600 system) used for reagent preparation. Distilled methanol and concentrated nitric acid (Analytical-reagent grade) also were used for sample preparation. Mixture of $40 \% \mathrm{Mg}\left(\mathrm{NO}_{3}\right)_{2} \mathrm{w} / \mathrm{v}$ and $4 \% \mathrm{w} / \mathrm{v} \mathrm{MgO}$ solution was used as the ashing aid. Standard solutions of arsenic were prepared from $1000 \mathrm{mg} / \mathrm{L}$ commercially available AAS grade stock solution by dilution in $1 \% \mathrm{v} / \mathrm{v}$ nitric acid. Experimental stock solutions of arsenic were prepared using deionized water, acidified with $2 \%$ v/v analytical grade nitric acid to $\mathrm{pH} 3$ and stored in $4{ }^{0} \mathrm{C}$ refrigerator.

\subsection{INSTRUMENTATION}

Grinding mill (National 176, made in china) was used for grinding the dried chicken muscles. A GBC Model 932 plus (Australia) atomic absorption spectrometer, equipped with a deuterium background corrector, pyrocoated graphite tube with system 3000 automated graphite furnace and PAL 3000 
programmable automatic sample loader, was used for the arsenic analysis. The instrumental parameters for both techniques are given in Table 1. Heraeus M 104 Muffle furnace was used for sample digestion. The operating parameters for working element were set as recommended by the manufacturer.

\subsection{DIGESTION METHOD}

Dry ash preparation method was performed as the digestion method. The samples were weighed $(0.30$ $\mathrm{g}$, dry weight) into $25 \mathrm{ml}$ silica dishes crucibles. About $10 \mathrm{ml}$, a mixture of $40 \% \mathrm{w} / \mathrm{v} \mathrm{Mg}\left(\mathrm{NO}_{3}\right)_{2}$ and $4 \% \mathrm{MgO}$ w/v was added. Then $5 \mathrm{ml}$ of methanol was added to each sample and mixed thoroughly. The samples were dried on an oven at $120{ }^{\circ} \mathrm{C}$ overnight, until they were thoroughly carbonized. The samples were transferred to a cool $\left(<50{ }^{\circ} \mathrm{C}\right)$ muffle furnace and the temperature was raised gradually to $450{ }^{\circ} \mathrm{C}$ for 08 hours. After allowing the ashes cool to room temperature, ashes were dissolved in 5 $\mathrm{ml}$ of concentrated $\mathrm{HNO}_{3}$ and $10 \mathrm{ml}$ of deionized water. Analytical banks were prepared in a similar manner without the insertion of a sample. Precautions were taken to avoid splattering of liquid from the crucible. Cleaned dried Teflon bottles were used to store sample solutions in refrigerator.

\section{RESULTS AND DISCUSSION}

Moisture content was determined by drying samples to a constant weight in an electric oven at $120 \pm 5$ ${ }^{0} \mathrm{C}$, and was calculated as percent of water loss. The moisture contents of the breast muscle, liver muscle and heart were 63-69\%, 73\% and 73\%, respectively. The cooked chicken samples were contained range of 60-63\% moisture percentage. According to the United States, Department of agriculture, Food safety and inspection services, a whole broiler chicken contains $66 \%$ water before cooking and $60 \%$ water after cooking.

The GFAAS techniques were used for the determination of As in fresh samples of broiler chicken

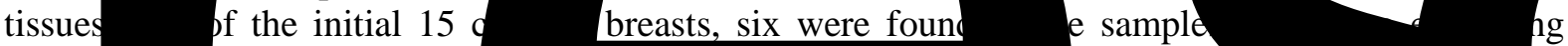
maximum permissible level of $0.5 \mu \mathrm{g} \mathrm{g}^{-1}$ total arsenic. The mean total arsenic concentration of Brand "A" chicken breasts was taken higher value than the maximum permissible level (Table 1), (Figure 1) while other brands revealed values below the maximum permissible level. The mean total arsenic concentrations of various tissues were abbreviated with standard deviation and their ranges in Table 1 . Table demonstrates the mean total arsenic concentration of chicken breast, liver and heart tissues on dry basis as well as wet basis. Some of the raw chicken samples and Village chicken sample tested had no detectable arsenic (ND) (Table 2). Values of total arsenic in breast muscles were observed on dried basis in the range of 1.89-2.49, 1.34-1.64 and ND-2.60 $\mu \mathrm{g} \mathrm{g}^{-1}$ for brands $\mathrm{A}, \mathrm{B}$, and C, respectively (Table 1). Their mean values were exposed as $2.17 \pm 0.25,1.49 \pm 0.11$ and $0.11 \pm 0.10 \mu \mathrm{g} \mathrm{g}^{-}$

1. The total arsenic values ranged as 0.83-1.49 and, 4( )-42(()-3(<50)] TJET3(0.1)11 rand C, 
Table 1: Abbreviation of values in the analysis

\begin{tabular}{|l|l|l|l|l|}
\hline \multirow{2}{*}{ Sample type } & \multicolumn{2}{l|}{$\begin{array}{l}\text { Concentration } \\
\text { dry basis } / \boldsymbol{\mu g} \mathbf{g}^{-1}\end{array}$} & \multicolumn{2}{l|}{$\begin{array}{l}\text { Concentration } \\
\text { wet basis } / \boldsymbol{\mu g} \mathbf{~}^{-1}\end{array}$} \\
\cline { 2 - 5 } & Mean & Range & Mean & Range \\
\hline Brand A (breast) & $2.17 \pm 0.25$ & $1.89-2.49$ & $0.75 \pm 0.08$ & $0.65-0.85$ \\
\hline Brand B (breast) & $1.49 \pm 0.11$ & $1.34-1.64$ & $0.47 \pm 0.03$ & $0.42-0.52$ \\
\hline Brand C (breast) & $0.11 \pm 0.10$ & ND-2.60 & $0.04 \pm 0.04$ & ND - 0.08 \\
\hline Brand C ( liver) & $1.22 \pm 0.26$ & $0.83-1.49$ & $0.33 \pm 0.07$ & $0.23-0.40$ \\
\hline Brand C ( heart) & $1.13 \pm 0.54$ & $0.34-1.70$ & $0.30 \pm 0.16$ & $0.09-0.45$ \\
\hline
\end{tabular}

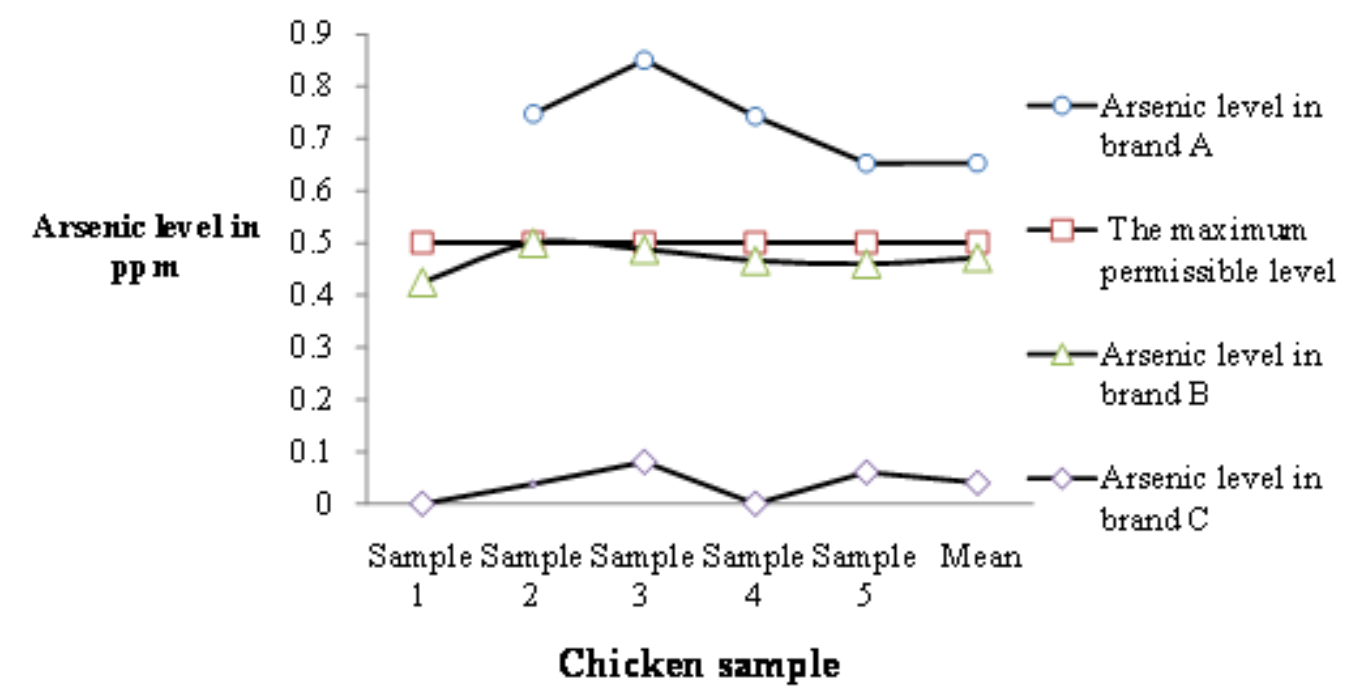

Figure 1: Comparison of arsenic concentrations in chicken breast tissues available in Sri Lankan market

Overall mean total arsenic concentration in chicken breast tissues was found to be $0.42 \mu \mathrm{g} \mathrm{g}^{-1}$, which is higher than 0.030-0.086 $\mu \mathrm{g} \mathrm{g}^{-1}$ observed in a market study in the United States, during 1991-1996 by Tao \& Bolger, and also lower than to $3.27 \mu \mathrm{g} \mathrm{g}^{-1}$ reported in Pakistan by Abdul Qadir Shah et al in 2007 .The estimated mean total arsenic value in liver tissue was $0.33 \mu \mathrm{g} \mathrm{g}^{-1}$, which is coincident with the values $0.33-0.43 \mu \mathrm{g} \mathrm{g}^{-1}$ reported by Korsrud et al [1985]; Salisbury, Chan, \& Saschenbrecker, [1991] in the literature and lower than the value $4.57 \mu \mathrm{g} \mathrm{g}^{-1}$ reported by Abdul Qadir Shah et al in 2007. A noteworthy difference was also observed between heart tissues and breast muscles. Thus accumulation of As was found to be higher in liver and heart as compared to that in breast muscles. The higher As concentration observed in different tissues of chickens was consistent with the use of chicken feed containing additives including As compounds and the high accumulation of As in liver tissues was also consistent with other toxic metal accumulation in liver tissues of chicken. This kind of enhancement on arsenic concentration in broiler chicken tissues while village chicken containing not detectable level of arsenic, strongly suggest that the arsenic compounds are extensively added to the feed of animals-particularly to chickens for the control of coccidial intestinal parasites and to improve feed efficiency. 
Arsenic was tested among the cooked chicken breasts which were subjected to different cooking recipes and was found that the cooked chicken tissues had total arsenic close to $1 \mathrm{ppm}$ (Table 2); none of them were in the undetectable range.

Table 2: Variation of the arsenic concentration in chicken breast tissues cooked by different recipes

\begin{tabular}{|c|c|c|c|}
\hline \multicolumn{2}{|l|}{ Sample } & $\begin{array}{l}\text { As concentration } \\
\text { in cooked samples } \mu \mathrm{g} / \mathrm{g} \\
(\text { dry basis) }\end{array}$ & $\begin{array}{l}\text { As concentration } \\
\text { in cooked samples } \\
\mu \mathrm{g} / \mathrm{g} \text { (wet basis) }\end{array}$ \\
\hline \multicolumn{3}{|c|}{ Maximum permissible level of arsenic } & 0.5000 \\
\hline Fresh sample & 1 & 2.92 & 1.07 \\
\hline Cooked by Distilled water & 2 & 3.70 & 1.44 \\
\hline Conventional cooked & 3 & 2.72 & 1.07 \\
\hline Cooked in lime solution & 4 & 6.22 & 2.41 \\
\hline Cooked in tamarind solution & 5 & 5.88 & 2.31 \\
\hline Cooked in garlic solution & 6 & 3.70 & 1.47 \\
\hline frying & 7 & 3.33 & 1.94 \\
\hline
\end{tabular}

Conventionally cooked chicken sample contained approximately the same amount of arsenic $(1.07 \mu \mathrm{g}$ $\left.\mathrm{g}^{-1}\right)$ like fresh chicken breast. It has been illustrated that no considerable effect for arsenic level in the breast tissues which are subjected for conventional cooking. The figures show that the total arsenic levels in the samples which were cooked by using lime and tamarind solutions ( 2.41 and $2.31 \mu \mathrm{g} \mathrm{g}^{-1}$, respectively) are twice than the levels in fresh sample $\left(1.07 \mu \mathrm{g} \mathrm{g}^{-1}\right)$. In other hand the figures show that the chicken tissues cooked in garlic extract also contain relatively higher amount of arsenic (1.47 $\left.\mu \mathrm{g} \mathrm{g}^{-1}\right)$. The most acceptable reason for above observations is the pieces of chicken tissues which were subjected to above three cooking recipes (cooked samples which have enhanced arsenic concentrations than the fresh sample) have high potential to contain relatively higher amount of arsenic than other two pieces (cooked sample which have relatively the same amount of arsenic to fresh sample) of tissues (Jennifer Seiter's [2007]).This might be the reason for obtaining an unexpected concentration of arsenic $\left(1.44 \mu \mathrm{g} \mathrm{g}^{-1}\right)$ for the sample which was cooked by using distilled water.

Chicken consumption has increased in developing countries such as Sri Lanka due to shortage of other meat resources and due to high cost which may indicate a need to review assumptions regarding overall ingested As intake. At investigation was done in Canada regarding arsenic speciation in Canadian food samples, was suggeted that $65 \%$ of As in poultry and meat is inorganic (Levine et al., 1988; Weiler, 1987). This estimation was used in the 1988 U.S. Environmental Protection Agency risk assessment regarding the risk of skin cancer associated with the ingested inorganic arsenic, and is currently used as the basis of discussions of As exposure and health effects (Abernathy, 2001).

On the basis of the above mentioned assumption, we calculated total Arsenic as well as $65 \%$ of total As as inorganic As. The intake of As was calculated on wet basis, by measuring moisture content of each tissue. We calculated the intake of As on the consumption of three masses $60 \mathrm{~g}, 350 \mathrm{~g}$, and $500 \mathrm{~g}$ per day per person (about $60 \mathrm{Kg}$ ). The calculated inorganic arsenic intake of average consumer $(60 \mathrm{~g}$ per day) would be $0.49,0.31$ and $0.02 \mu \mathrm{g} / \mathrm{kg}$ /day from brands " $\mathrm{A}$ ", "B" and "C" respectively, for a person weighing $60 \mathrm{~kg}$ and contributes $23.77,14.6$ and 1.09 percentages by chicken alone out of the FAO/WHO tolerable daily intake $(2.1 \mu \mathrm{g} / \mathrm{kg} /$ day $)$ which is receive from all dietary sources. 
Table 3: Average person's inorganic arsenic injection by chicken consumption and percentage contribution for FAO/WHO (Food and Agriculture Organization/ World Health Organization) tolerable daily intake

\begin{tabular}{|c|c|c|c|c|c|c|c|}
\hline \multirow{3}{*}{$\begin{array}{l}\text { Daily chicken } \\
\text { consumption } \\
\text { /gram }\end{array}$} & \multirow{3}{*}{$\begin{array}{l}\text { Types of } \\
\text { consumers }\end{array}$} & \multicolumn{6}{|c|}{$\begin{array}{l}\text { Inorganic arsenic ingestion for average weight person } \\
(60 \mathrm{~kg})\end{array}$} \\
\hline & & \multicolumn{3}{|c|}{ Daily ( $\mu g$ ) } & \multicolumn{3}{|c|}{$\begin{array}{l}\text { Percentage contribution for } \\
\text { FAO/WHO tolerable daily } \\
\text { intake by chicken alone }\end{array}$} \\
\hline & & $\begin{array}{l}\text { Brand } \\
\text { A }\end{array}$ & $\begin{array}{l}\text { Brand } \\
\text { B }\end{array}$ & $\begin{array}{l}\text { Brand } \\
\text { C }\end{array}$ & $\begin{array}{l}\text { Brand } \\
\text { A }\end{array}$ & $\begin{array}{l}\text { Brand } \\
\text { B }\end{array}$ & Brand C \\
\hline 60 & $\begin{array}{l}\text { Average } \\
\text { consumers }\end{array}$ & 0.49 & 0.306 & 0.023 & 23.77 & 14.6 & 1.09 \\
\hline 350 & $\begin{array}{l}\text { chicken } \\
\text { lovers }\end{array}$ & 2.84 & 1.79 & 0.13 & 135.12 & 85.14 & 6.32 \\
\hline 500 & $\begin{array}{l}\text { crazy for } \\
\text { chicken }\end{array}$ & 4.05 & 2.55 & 0.19 & 193.04 & 121.63 & 9.02 \\
\hline
\end{tabular}

If one in a hundred of us (let's call them "chicken lovers") eats more than $350 \mathrm{~g}$ of chicken per day, he may ingest particularly $2.84,1.79$ and $0.13 \mu \mathrm{g} / \mathrm{kg} /$ day from brands " $\mathrm{A}$ ", "B" and "C" ; it would be $135.12,85.14$ and 6.32 percentages out of the tolerable daily intakes for all dietary sources. If the people who are crazy for chicken eat at least $500 \mathrm{~g}$ of chicken per day, they could be expected to ingest $4.05,2.55$ and $0.19 \mu \mathrm{g} / \mathrm{kg} /$ day per day by chicken alone and this could translate into 193.04, 121.63, and 9.02 percentage contribution in brands " $A$ ", "B", and "C, respectively (Table 3 ).

An adult drinking 1 liter per day of water contaminated with arsenic at the WHO's older standard of $50 \mathrm{ppb}$ would be expected to ingest around 50 micrograms of inorganic arsenic per day. Over a lifetime, this person's arsenic exposure would give them an additional 13-in-1000 life time risk of dying, over and above their risks for cancer due to other reasons. For the several million Sri Lankan who currently drink water contaminated with at least this much arsenic, there would be a further cancer risk from their additional arsenic exposure from eating chicken. For "chicken lovers", their ingestion of arsenic from chicken and therefore their heightened risk of developing cancer could be about the same as that from drinking water contaminated with arsenic at the $50 \mathrm{ppb}$ WHO older standard. Using the estimates generated by this study Sri Lankan who are simply "average" consumers of chicken, as well as of water contaminated with arsenic up to the WHO standard $50 \mathrm{ppb}$, could also significantly elevate their risk of cancer, but not by nearly as much as do chicken lovers and people who are crazy for chicken.

\section{CONCLUSION}

The dry ash preparation method has been demonstrated to be an efficient methodology for the determination of total Arsenic in broiler chicken by graphite furnace atomic absorption spectrometry. 
The accuracy of method was checked by spiky recovery test. The good analytical features of the method allow for its application for routine analysis of large number of samples and a variety of foodstuff.

As concentrations included in the present study are important for the provision of toxicochemical information on the added As levels in chicken feed. And also this investigation concludes;

Arsenic is common in most of the chicken breast, liver and heart tissue samples available in Sri Lankan market.

Most of the brand "A" breast tissue samples violate the tolerances for total residue of arsenic in chicken meat set by the FDA.

Plenty of other brand's breast tissue samples also violate the FDA's maximum permissible level. Liver and heart tissue contain relatively higher amount total arsenic than breast tissue.

Any of the cooking recipes do not help to eliminate arsenic from chicken breast tissues.

All the types of consumers (Average consumers, chicken lovers, and people who are crazy for chicken) contribute a considerable portion of inorganic arsenic for the tolerable daily intake of inorganic arsenic through the chicken brand " $\mathrm{A}$ " and "B".

\section{REFERENCES}

Abernathy, C. (2001). Exposure and health effects. In: UN synthesis report on arsenic in drinking water (pp. 1-100).Washington, DC: World Health Organization. Available:

<http://www.who.int/water_sanitation_health/dwq/en/arsenicun3. pdf> [accessed 4 August 2010]

Chapman, H.D., \& Johnson, Z.B., 2002. Use of antibiotics and roxarsone in broiler chickens in the USA: analysis for the years 1995 to 2000. J. Poultry Science, 81, 356-364.

Chiou H.Y., Hsueh Y.M., Liaw K.F., Horng S.F., Chiang M.H., Pu Y.S., et al. 1995. Incidence of internal cancers and ingested inorganic arsenic: a seven-year follow-up study in Taiwan. J. Cancer Res, 55:1296-1300.

Gonsebatt M.E., Vega L., Salazar A.M., Montero R., Guzman P., Blas J., et al., 1997. Cytogenetic effects in human exposure to arsenic. J. Mutat Res 386:219-228.

Hopenhayn-Rich C., Browning S.R., Hertz-Picciotto I., Ferreccio C., Peralta C., Gibb H., 2000. Chronic arsenic exposure and risk of infant mortality in two areas of Chile. J. Environ Health Perspect 108:667-673.

Hsueh Y.M., Cheng G.S., Wu M.M., Yu H.S., Kuo T.L., Chen C.J., 1995. Multiple risk factors associated with arsenic-induced skin cancer: effects of chronic liver disease and malnutritional status. J. Cancer Res 71:109114.

Jackson, B.P., and Miller, W.P., 2000. Effectiveness of phosphate and hydroxide for desorption of arsenic and selenium species from iron oxide. J. Environmental Quality, 64, 1616-1622.

Korsrud, G., Meldrum, J., Salisbury, C., Houlahan, B., Saschenbrecker, P., \& Tittiger, F., (1985). Trace element levels in liver and kidney from cattle, swine and poultry slaughtered in Canada. J. Canadian Journal of Comparative Medicine, 49, 159-163.

Kurttio P, Pukkala E, Kahelin H, Auvinen A, Pekkanen J., 1999. Arsenic concentrations in well water and risk of bladder and kidney cancer in Finland. J. Environ Health Perspect 107:705-710. 
Levine, T., Marcus, W., Chen, C., Rispin, A., Scott, C. S., \& Gibb, H., 1988. Report on ingested inorganic arsenic: skin cancer, nutritional essentiality. Washington, DC: U.S. Environmental Protection Agency.

Lewis D.R., Southwick J.W., Ouellet-Hellstrom R., Rench J., Calderon R.L., 1999. Drinking water arsenic in Utah: a cohort mortality study. J. Environ Health Perspect 107:359-365.

Lubin J.H., Pottern L.M., Stone B.J., Fraumeni J.F., 2000. Respiratory cancer in a cohort of copper smelter workers: results from more than 50 years of follow-up. J. Am J Epidemiol 151:554-565.

Lasky, T., Sun, W., Kadry, A., \& Hoffman, M. K., 2004. Mean total arsenic concentrations in chicken 19982000 and estimated exposures for consumers of chicken. J. Environmental Health Perspectives, 112, 18-21.

Salisbury, C., Chan, W., \& Saschenbrecker, P., (1991). Multielement concentrations in liver and kidney tissues from five species of Canadian slaughter animals. J. Association of Official Analytical Chemists, 74, 587-591.

Seiter, J., 2007. Direct Speciation and Distribution of Dietary Arsenic in Chicken Excreta and Tissues, published in The ASA-CSSA-SSSA International Annual Meetings.

Shah, A.Q., Kazi G. T., Arain, B.M., Jamali, M.K., Afridi H.I, Jalbani, N., kandhro, G. A., Baig, J. A., sarfraz R. A., Ansari R., 2009. Comparison of electrothermal and hydride generation atomic absorption spectrometry for the determination of total arsenic in broiler chicken, J. Food Chemistry Volume 113, Issue 4, Pages 1351-1355.

Szkoda, J., Zmudzki, J., \& grzebalska, A., 2006. Determination of arsenic in biological material by hydride generation atomic absorption spectrometry method. J. Bulletin Veterinary Institute. 50, 269-272.

Tao S.S., Bolger P.M., 1999. Dietary arsenic intakes in the United States: FDA Total Diet Study, September 1991-December 1996. J. Food Addit Contam 16:465-472.

Wershaw, R. L., Garbarino, J. R., \& Burkhardt, M. R., (1999). Roxarsone in natural water systems. In: F. D. Wilde et al., (Ed.), Proceedings of the conference on the effects of animal feeding operations on water resources and the environment (pp.95-96). Fort Collins: Colorado, 30 August-1 September. US Geological Survey OpenFile Report 00-204.

Weiler, R. 1987. Percentage of inorganic arsenic in food: a preliminary analysis. Report No. 87-48-45000-057. Toronto, Canada: Ontario, Canada Ministry of the Environment. 